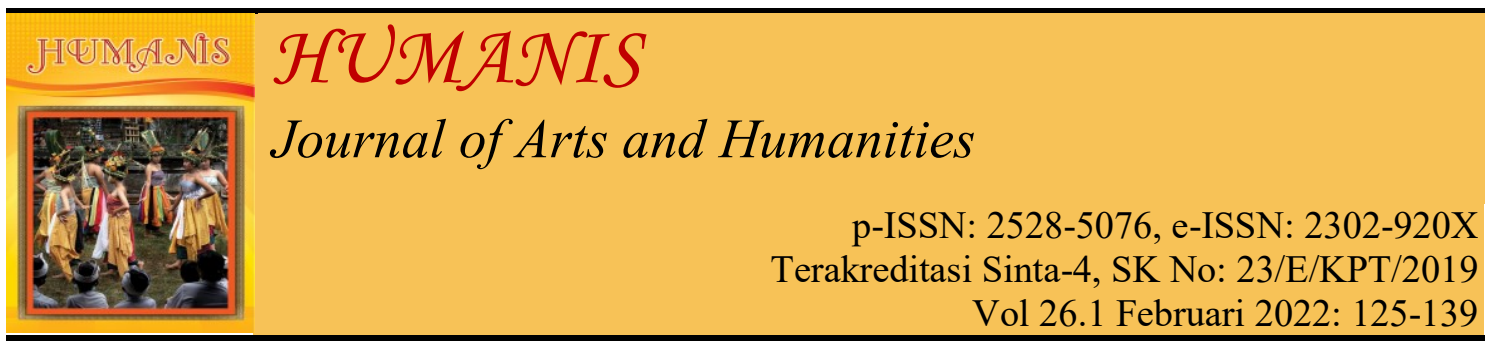

\title{
Ujaran Kebencian dalam Kolom Komentar Media Berita Daring Babe
}

\section{Anggie Ray Salvatore, I Nyoman Suparwa, Made Sri Satyawati}

Universitas Udayana, Denpasar, Bali

Email Korespondensi: anggie.salvatore@gmail.com, nym_suparwa@unud.ac.id, srisatyawati@gmail.com

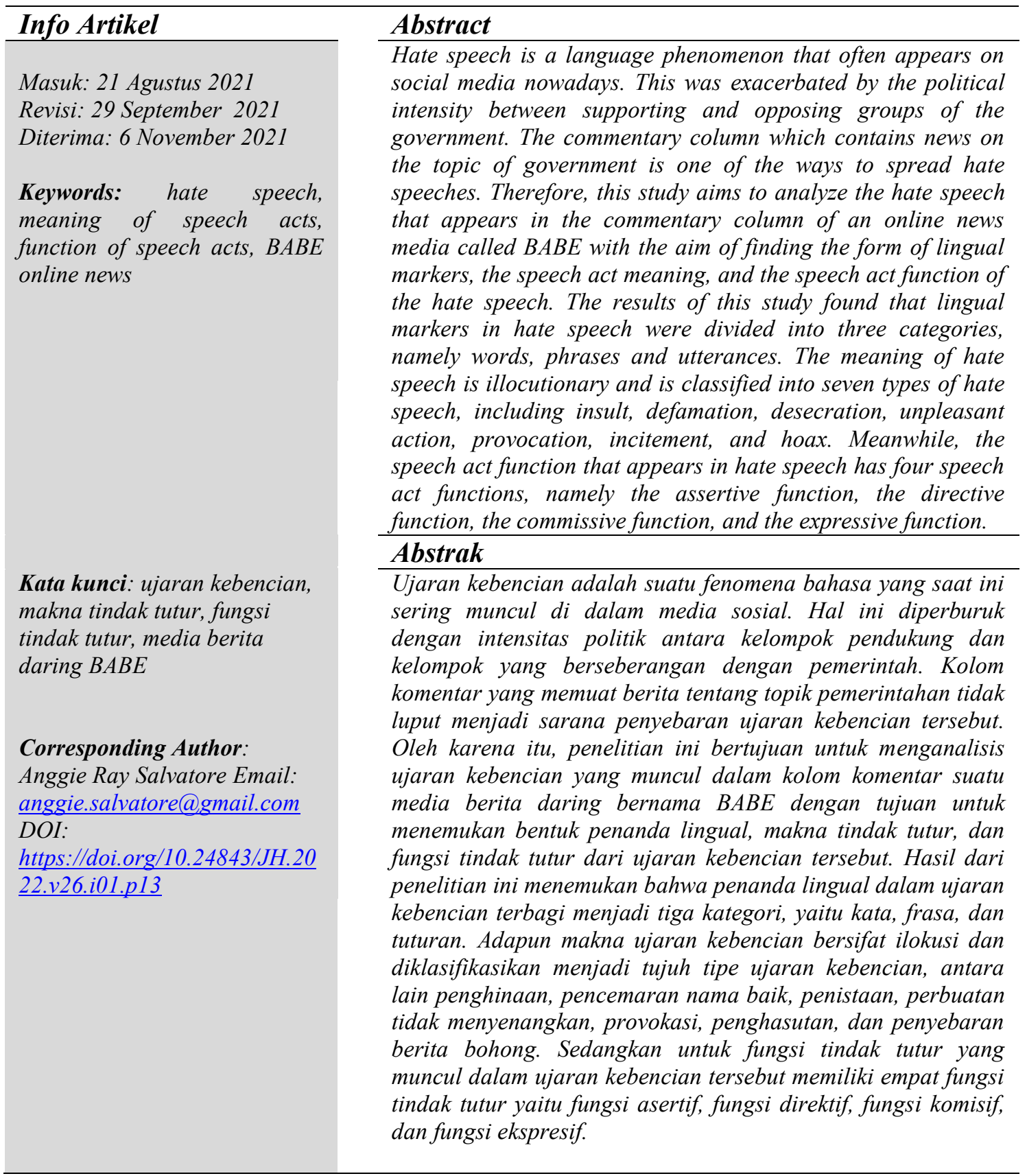




\section{PENDAHULUAN}

Bahasa merupakan alat pengungkap emosi (Chaer, 2010:20). Dengan bahasa, penutur dapat mengungkapkan pendapat dan emosinya. Dengan memperlihatkan emosi dalam berkomunikasi, penutur dapat dengan mudah menyampaikan maksud dari tuturan yang disampaikan sehingga hal itu mempermudah pendengar untuk memahami pikiran dan perasaan dari si penutur. Penyampaian pendapat tersebut dapat berupa sebuah tuturan lisan maupun tulisan.

Namun banyak masyarakat Indonesia yang menyampaikan pendapat secara salah. Bahasa digunakan atas dasar kebencian kemudian dijadikan alat untuk meraih keinginan pribadi. Bahasa tidak lagi 'objektif" tapi lebih "subjektif" sesuai keinginan dari penutur. Hal inilah yang menyebabkan munculnya ujaranujaran kebencian yang tidak bertanggung jawab.

Mengacu pada media penyebarannya, media sosial adalah satu sarana yang sering digunakan dalam menyebarkan ujaran kebencian. Media sosial sudah dianggap sebagai tulang punggung sarana komunikasi dalam era digital ini (Kemendag, 2014: 43). Oleh karena itu, karena sifatnya yang global, langsung dan partisipatif, media sosial telah menjadi ruang untuk ekspresi dan penyebaran ide dan keyakinan yang terkadang intoleran (Isasi dan Juanatey, 2016).

Salah satu media sosial online yang kurang terkontrol dalam kolom komentarnya adalah $B A B E$. Mungkin banyak orang awam yang kurang mengetahui seluk beluk media sosial ini. $B A B E$ sendiri merupakan sebuah media berita online yang mana pembaharuan beritanya dianggap cukup cepat dalam membahas isu-isu baru yang terjadi dalam masyarakat. Apalagi aplikasi ini terkadang sudah ada dalam smartphone android tanpa perlu adanya proses pengunduhan. Akan tetapi kemudahan dalam mengakses berita online ini tidak diikuti dengan penyaringan komentar yang berbobot. Banyak ditemukan ujaran kebencian yang muncul di setiap beritanya, khususnya berita yang bertema pemerintahan. Terlihat bahwa kesadaran masyarakat dalam berkomentar tidak diikuti dengan keinginan untuk menjaga perasaan orang lain. Ujaran kebencian dianggap sebagai suatu alat mengungkapkan perasaan penulis dalam memberi komentar suatu berita saja.

Berdasarkan permasalahan di atas, kajian mengenai ujaran kebencian ini perlu dilakukan sebagai salah satu tindakan pencegahan persebaran ujaran kebencian yang semakin meluas. Austin (1962: 12) menyebutkan bahwa pada dasarnya saat seseorang menyatakan sesuatu, dia juga melakukan sesuatu. Tindakan inilah yang dalam ilmu pragmatik dinamakan sebagai tindak tutur (speech act). Oleh karena itu, penelitian ini berfokus pada analisis bentuk, makna, dan fungsi tindak tutur pada ujaran kebencian yang muncul dalam kolom komentar media berita online $B A B E$ yang dikhususkan pada tema pemerintahan. Hasil penelitian ini diharapkan dapat memberikan gambaran mengenai perkembangan fenomena ujaran kebencian yang saat ini muncul dalam interaksi masyarakat di Indonesia sehingga memberikan kesadaran bagi masyarakat untuk menjaga tindak tutur sesuai norma dan hukum yang berlaku.

\section{METODE DAN TEORI}

Penelitian ini bersifat kualitatif yaitu menjelaskan suatu fenomena ujaran kebencian yang muncul dalam interaksi masyarakat dalam kolom komentar media berita online $B A B E$. Metode pengumpulan data yang digunakan adalah metode simak dan metode cakap (Sudaryanto, 2015:2). Metode simak dan cakap ini diwujudkan dengan melakukan dokumentasi terhadap data kemudian dikelompokkan sesuai dengan jenisnya. 
Sedangkan analisis data mengenai ujaran kebencian, menggunakan metode padan dan metode distribusional (Sudaryanto, 2015:16). Alasan penggunaan kedua metode ini karena suatu ujaran kebencian akan menggunakan alat penentu bahasa itu sendiri (makna tuturan) dan unsur luar bahasa (konteks).

Penelitian ini menggunakan teori pragmatik dimana bentuk, makna, dan fungsi akan dianalisis menggunakan teori tindak tutur. Bentuk penanda lingual pada ujaran kebencian terbagi menjadi tiga yaitu kata, frasa, dan tuturan. Makna sebuah tuturan dapat diklasifikasikan menjadi tiga, yaitu makna lokusi, makna ilokusi dan makna perlokusi (Austin, 1962: 25). Sedangkan fungsi tindak tutur dapat diklasifikasikan menjadi lima, yaitu: fungsi asertif, fungsi direktif, fungsi komisif, fungsi ekspresif, dan fungsi deklaratif (Searle, 1971:17).

\section{HASIL DAN PEMBAHASAN}

\section{A. Penanda Lingual dalam Ujaran Kebencian}

Pada hakekatnya ujaran kebencian adalah sebuah kekerasan verbal yang melanggar etika komunikasi. Hal ini dikarenakan perbedaan pandangan yang menimbulkan perasaan permusuhan antara satu sama lain. Setiap ujaran kebencian pasti memiliki suatu penanda lingual. Penanda ini dapat berbentuk kata, frasa, maupun tuturan.

1. Penanda Lingual Berbentuk Kata

Penanda lingual berbentuk kata pada ujaran kebencian sangat mudah ditemukan. Hal ini disebabkan karena kata merupakan satuan bahasa yang memiliki makna dan dapat berdiri sendiri.

Sebagai contoh:

(1A) goblok, orang sering

(Sumber berita: FPI Jabar: FPI Belum

Pernah Bunuh Orang - 30 Desember 2020)

Pada data (1A), FPI Jabar melakukan klarifikasi bahwa FPI adalah ormas yang tidak melakukan kekerasan hingga membunuh orang. Akan tetapi pada kolom komentar ada seseorang yang tidak setuju dengan berita tersebut dan menuliskan "goblok, orang sering". Kata goblok disini merupakan suatu penanda ujaran kebencian berbentuk hinaan yang mengganggap isi berita tersebut yaitu FPI Jabar merupakan kumpulan orang yang bodoh dan memiliki gangguan mental karena dianggap memutar balikkan kenyataan sehingga disebut goblok oleh penulis komentar tersebut.

Tabel 1. Penanda Lingual Kata pada Ujaran Kebencian

\begin{tabular}{ccc}
\hline No & Kategori & Contoh \\
\hline 1 & Pengasosiasian hewan & cebong, kodok, kadrun/kadal gurun \\
2 & Profesi rendah & jongos \\
3 & Plesetan nama & jokodok, jijik \\
4 & Kotoran & bangkai, sampah \\
5 & Kelemahan fisik & ompong \\
6 & Sifat buruk & pecundang, penjilat, munafik \\
7 & Gangguan mental & goblok, tolol \\
\hline
\end{tabular}


Pada tabel 1 diatas, pengasosiasian hewan adalah penanda lingual kata yang paling sering ditemukan. Kata cebong dan kodok diasosiasikan kepada kelompok orang yang mendukung pemerintah, sedangkan kadrun atau kadal gurun diasosiasikan kepada kelompok oposisi yang berseberangan dari pemerintah. Oleh karena data yang dianalisis berfokus pada tema pemerintahan maka penggunaan katakata ini sering ditemukan sebagai suatu hinaan kepada orang atau kelompok yang berbeda pandangan dengan penutur ujaran kebencian di kolom komentar tersebut.

\section{Penanda Lingual Berbentuk Frasa}

Frasa adalah salah satu penanda lingual yang dapat menunjukkan adanya sebuah ujaran kebencian. Pada tabel 2 dibawah ini, kita dapat melihat adanya empat klasifikasi ujaran kebencian yang muncul dalam kolom komentar media berita daring $B A B E$.

Tabel 2. Penanda Lingual Frasa pada Ujaran Kebencian

\begin{tabular}{ccc} 
No & Kategori & Contoh \\
\hline 1 & Penekanan ujaran kebencian & dasar kadrun, dasar tolol, jongos Rizik \\
2 & $\begin{array}{c}\text { Dua kata yang awalnya netral } \\
\text { menjadi frasa yang merendahkan }\end{array}$ & palsu, anak haram, muka ndeso \\
3 & $\begin{array}{c}\text { Frasa itu memiliki makna yang } \\
\text { negatif }\end{array}$ & sampah masyarakat, kelompok ISIS \\
4 & Frasa yang berbentuk umpatan & $\begin{array}{c}\text { muak liat muka lu, omongannya kayak } \\
\text { kentut, tembak mati aja }\end{array}$ \\
\hline
\end{tabular}

Salah satu contoh frasa pada tabel 2 ada dalam data (1B) berikut ini

(1B) Bantai aja rizik, habib palsu

(Sumber berita: Rizieq Shihab: Indonesia

Perlu Revolusi Ahlak - 2 Desember 2020)

Pada data (1B), berita yang ditunjukkan merupakan suatu pemberitaan mengenai Habib Rizik Shihab yang memberikan pendapat bahwa Indonesia perlu adanya revolusi ahlak karena tidak sesuai dengan ajaran agama islam. Hal ini menimbulkan perasaan tidak senang oleh penutur yang kemudian menghasut pembaca yang lain dengan memberikan komentar bahwa Habib Rizik merupakan habib palsu. Kata habib sendiri merupakan kata yang netral akan tetapi ketika diberi tambahan dengan kata palsu menghasilkan frasa yang bersifat negatif.

\section{Penanda Lingual Berbentuk Tuturan}

Penanda lingual berbentuk tuturan pada ujaran kebencian pada hakekatnya dapat berbentuk klausa maupun kalimat. Tuturan tersebut akan dilihat sebagai suatu bentuk kesatuan yang menunjukkan perasaan benci penutur dan dapat menimbulkan rasa permusuhan.

Contoh:

(1C) Selama rezim ini berkuasa kalian seneng berkoar...Tunggu wktunya selesai kalian gk bakalan bisa apa pa, bersenang senanglah dahulu kalian.

(Sumber berita: Kerumunan Terjadi Saat Kunjungan Presiden - 24 Februari 2021)

Pada tuturan (1C) tersebut terlihat penutur tidak terima dan marah atas perlakuan hukum antara presiden dan ketua FPI, Habib Riziek yang penutur anggap tidak adil. Pada tuturan tersebut tidak ditemukan suatu penanda lingual ujaran kebencian berbentuk kata atau frasa, akan tetapi jika kita pahami maksud dari penutur tersebut maka kita dapat memaknai suatu bentuk ancaman dari tulisan tersebut. Jadi dalam penanda lingual berbentuk tuturan, makna dari 
tuturan adalah faktor penting yang melandasi apakah tuturan itu merupakan ujaran kebencian atau tidak.

\section{B. Makna Tindak Tutur dalam Ujaran Kebencian}

Suatu ujaran pasti memiliki suatu makna. Menurut Austin (1962), makna suatu ujaran dapat terbagi menjadi makna lokusi, makna ilokusi, dan makna perlokusi. Makna lokusi adalah makna konseptual dimana tuturan tersebut bermakna denotatif atau tanpa melihat konteks. Makna ilokusi adalah makna kontekstual dimana tuturan memiliki makna berdasarkan konteks saat tuturan itu muncul. Sedangkan makna perlokusi merupakan tuturan hasil dari tuturan ilokusi yang sebelumnya muncul. Oleh karena suatu ujaran kebencian memerlukan konteks dalam memahami makna tuturan tersebut maka ujaran kebencian memiliki makna ilokusi dalam setiap tuturannya.

Pemaknaan suatu ujaran kebencian dilihat dari konteks dimana tuturan itu muncul dapat membagi ujaran kebencian menjadi tujuh klasifikasi, yaitu:

\section{Penghinaan}

Jika suatu ujaran memiliki makna ilokusi dengan konteks kesengajaan, menyerang kehormatan atau nama baik seseorang, menuduhkan suatu hal yang memalukan, serta dengan maksud diketahui umum maka tuturan itu masuk dalam ujaran kebencian yang bersifat penghinaan.

Contoh:

(2A) Kau ini anak hasil kawin kontrak dengan arab kah

(Sumber berita: FPI Dibubarkan, Pemerintah Anggap FPI Berbahaya - 30 Desember 2020)

Pada tuturan (2A) tersebut terlihat penutur melakukan penghinaan terhadap FPI yang menyangkut pada SARA. Penutur disini menuduhkan hal yang memalukan dengan sengaja sehingga pembaca lain tahu.

\section{Pencemaran Nama Baik}

Jika suatu ujaran memiliki makna ilokusi dengan konteks adanya fitnah atau sesuatu hal yang merendahkan dan tidak benar mengenai diri seseorang atau kelompok dimana hal tersebut dipublikasikan kepada pihak lain sehingga mengakibatkan kerugian bagi objek tuturan maka tuturan itu masuk dalam ujaran kebencian yang bersifat pencemaran nama baik.

Contoh:

(2B) Turunin ja si jikodok tuh..beda2in perlakuan hukum?? Bener adanya kata mega, si jikodok cuma petugas partai, bukan presiden

(Sumber berita: Kerumunan Terjadi Saat Kunjungan Presiden - 24 Februari 2021)

Pada tuturan (2B) tersebut terlihat penutur melakukan pencemaran nama baik terhadap presiden Jokowi. Selain memplesetkan nama presiden, penutur juga memfitnah presiden dengan informasi yang tidak jelas.

\section{Penistaan}

Jika suatu ujaran memiliki makna ilokusi dengan konteks adanya publikasi secara luas mengenai ranah pribadi kelompok, ajaran, atau agama tertentu dan publikasi tersebut mengakibatkan pihak yang terkait merasa tersinggung.maka tuturan itu masuk dalam ujaran kebencian yang bersifat penistaan.

Contoh:

(2C) Sampah masyarakat, model gini kok dianggep ulama, kostumnya ga salah pake tuh..ganti aja kostum badut

(Sumber berita: Habib Rizieq: Pemerintah Tebang Pilih, Kasus Raffi Ahmad Dihentikan - 22 Januari 2021)

Pada tuturan (2C) tersebut terlihat penutur melakukan penistaan terhadap ulama yang merupakan pemuka agama Islam. Hal ini ditandai dengan dengan 
menyandingkan seorang ulama dengan sampah masyarakat dan badut.

\section{Perbuatan Tidak Menyenangkan}

Jika suatu ujaran memiliki makna ilokusi dengan konteks tuturan tersebut memakai ancaman kekerasan, menyatakan keinginan untuk mencelakakan pihak lain, serta memberi peringatan mengenai kemungkinan malapetaka yang bakal terjadi baik terhadap orang lain maka tuturan itu masuk dalam ujaran kebencian yang bersifat perbuatan tidak menyenangkan. Contoh:

(2D) Jangan dibebaskan, di bunuh aja si rijek

(Sumber berita: Desakan Bebaskan Habib Rizieq - 19 Desember 2020)

Pada tuturan (2D) tersebut terlihat penutur menyatakan sebuah ancaman dan keinginan untuk mencelakakan Habib Rizieq. Walaupun secara tindakan nyata, penutur tidak akan melakukan ancamannya tetapi secara tindak tutur, tuturan tersebut merupakan perbuatan yang tidak menyenangkan.

\section{Provokasi}

Jika suatu ujaran memiliki makna ilokusi dengan konteks kesengajaan terhadap diri seseorang atau kelompok tertentu dengan menuduhkan suatu hal, dengan maksud membangkitkan kemarahan dan berpikiran negatif maka tuturan itu masuk dalam ujaran kebencian yang bersifat provokasi.

Contoh:

(2E) Ormas yang paling penuh dengan dusta dan kebrutalan, jadi sangat betul untuk membasmi ormas yang penuh kebohongan ini

(Sumber berita: Mahmud MD Putar Video Pimpinan FPI Dukung ISIS - 30 Desember 2020)

Pada tuturan (2E) tersebut terlihat penutur menyatakan sebuah tuduhan bahwa FPI merupakan ormas yang penuh dusta dan kebrutalan sesuai dengan isi berita bahwa pimpinan FPI mendukung ISIS. Hal ini dapat memicu kemarahan dan pikiran negatif sehingga bersifat provokatif.

\section{Penghasutan}

Jika suatu ujaran memiliki makna ilokusi dengan konteks kesengajaan yang ditujukan kepada seseorang atau banyak orang dengan maksud untuk membangkitkan semangat supaya berbuat sesuatu sehingga menimbulkan perlawanan atau memberontak maka tuturan itu masuk dalam ujaran kebencian yang bersifat penghasutan.

Contoh:

(2F) Dasar teroris..tangkap aja pembohong

(Sumber berita: Mahmud MD Putar Video Pimpinan FPI Dukung ISIS - 30 Desember 2020)

Pada tuturan (2F) tersebut terlihat penutur menghasut pihak berwenang dan masyarakat luas untuk menangkap anggota FPI karena dianggap berbohong dengan diam-diam mendukung ISIS. Hal ini dilakukan dengan sengaja oleh penutur karena adanya perasaan tidak suka penutur terhadap ormas FPI tersebut.

\section{Penyebaran Berita Bohong}

Jika suatu ujaran memiliki makna ilokusi dengan konteks pemberitaan mengenai seseorang, kelompok yang beritanya disebarkan tidak lengkap, tidak jelas dan tidak diketahui kebenarannya sehingga publikasi tersebut mengakibatkan kerugian maka tuturan itu masuk dalam ujaran kebencian yang bersifat penyebaran berita bohong. Contoh:

(2G) Dinasti Politik dimana-mana (Sumber berita: Gibran Teguh dapat Rekomendasi Megawati, Gibran: Saya Minta Doa yang terbaik - 16 Juli 2020)

Pada tuturan (2G) tersebut terlihat penutur menyebarkan informasi bohong mengenai timbulnya dinasti politik 
karena Gibran sebagai anak presiden mencalonkan diri sebagai walikota Solo. Penyebaran berita bohong ini tidak berdasar karena merupakan opini penutur saja yang tidak dapat ditunjukkan kebenarannya tetapi dipublikasikan kepada pembaca lainnya.

\section{Fungsi Tindak Tutur dalam Ujaran Kebencian}

Tindak tutur merupakan suatu tuturan yang di dalamnya terdapat tindakan. Dengan mengucapkan sesuatu, penutur juga memiliki fungsi tertentu dalam tuturannya. Fungsi itu menurut Searle (1971:17) terbagi menjadi lima kategori yaitu asertif, direktif, komisif, ekspresif, dan deklaratif. Oleh karena penutur dalam kolom komentar pada media berita online BABE merupakan orang yang tidak memiliki kewenangan dalam tuturannya maka fungsi deklaratif tidak ditemukan dalam penelitian ini.

\section{Fungsi Asertif}

Fungsi asertif adalah suatu tuturan yang berfungsi untuk memberikan informasi kepada orang-orang mengenai sesuatu. Akan tetapi dalam ujaran kebencian informasi ini biasanya berbentuk informasi yang salah ataupun informasi yang menunjukkan kebencian penutur terhadap isi berita ataupun tokoh yang diberitakan. Adapun fungsi asertif yang ditemukan dalam ujaran kebencian di media online BABE ini terdiri dari bentuk berspekulasi, menyebutkan, menunjukan, melaporkan, dan menuntut.

\section{a) Berspekulasi}

Fungsi tindak tutur asertif berspekulasi adalah suatu tuturan yang bertujuan untuk menyampaikan suatu informasi yang kebenarannya belum diketahui secara pasti dan merupakan hasil pemahaman penutur dalam memberikan pendapatnya sehingga pendapat ini cenderung bersifat subjektif.
Sebagai contoh ada pada data di bawah ini:

(3A) Lah iya luntur.. kan berat ke china dari pada ke rakyat

(Sumber berita: Dulu Jadi Relawan Jokowi, Tokoh NU Kini Kecewa: Jokowi Luntur ke Jokowiannya - 12 Oktober 2020)

Pernyataan dari data (3A) merupakan sebuah informasi yang bersifat opini dan belum diketahui kebenarannya tetapi disebarkan kepada publik melalui kolom komentar. Penutur berspekulasi bahwa Jokowi lebih mendukung kerjasama dengan china dibandingkan memperhatikan rakyatnya sendiri. Oleh karena tidak jelasnya kebenaran informasi tersebut, penyebaran berita itu dapat dikategorikan sebagai penyebaran berita bohong yang merugikan pemerintah dan presiden Jokowi.

b) Menyebutkan

Fungsi dari tindak tutur asertif menyebutkan adalah memberikan informasi singkat kepada mitra tutur tanpa memberikan penjelasan yang lebih rinci. Penutur memberikan informasi dalam bentuk poin-poin saja sehingga mitra tutur harus memahami tuturan itu dengan pemahamannya sendiri. Sebagai contoh ada pada data di bawah ini:

(3B) Menghasut dan menghina seperti boss lu itu lebih kejam daripada membunuh..dasar badrun ngeyelan tolol (Sumber berita: FPI Jabar: FPI Belum Pernah Bunuh Orang - 30 Desember 2020)

Dari data (3B) dapat diketahui bahwa penutur mencoba menyebutkan nama Habib Rizieq sebagai pemimpin di FPI dengan kata ganti "boss" karena dianggap sebagai orang yang suka memerintahkan untuk menghina dan menghasut orang lain. 
c) Menunjukkan

Fungsi dari tindak tutur asertif menunjukan ini adalah memberikan informasi dengan menunjukkan suatu hal yang dianggap benar oleh penutur kepada mitra tutur. Sebagai contoh ada pada data di bawah ini:

(3C) Bawa senjata dan sajam, selalu bikin keributan, kegaduhan, itulah kadrun susah diatur, salam waras untuk yang waras.

(Sumber berita: Rizieq Shihab: Indonesia Perlu Revolusi Ahlak - 2 Desember 2020)

Data (3C) adalah fungsi asertif dengan bentuk menunjukan. Terlihat dari penuturan penulis mencoba menunjukan bukti dan kebenaran bahwa FPI adalah organisasi yang tidak baik. Walaupun demikian informasi ini tidak disertai bukti nyata dan terkesan kebenaran yang subjektif menurut pandangan penutur itu sendiri.

\section{d) Melaporkan}

Fungsi dari tindak tutur asertif melaporkan adalah memberikan sebuah laporan kepada mitra tutur yang sifatnya bisa subjektif ataupun objektif tergantung pada isi tuturan yang diberikan penutur kepada mitra tutur. Akan tetapi di dalam ujaran kebencian, laporan ini lebih bersifat subjektif dan dibesar-besarkan. Sebagai contoh ada pada data di bawah ini:

(3D) HRS DAN FPI BUKAN ISLAM yang sebenar-bbenar-nya!!! Tetapi penyebar AJARAN SESAT!

(Sumber berita: FPI Dibubarkan, Pemerintah Anggap FPI Berbahaya - 30 Desember 2020)

Pernyataan dari data (3D) adalah sebuah laporan yang disampaikan oleh penutur terhadap mitra tutur terkait dengan FPI yang merupakan organisasi yang bukan islam, namun adalah organisasi yang mengajarkan ajaran sesat. Hal ini merupakan bentuk ujaran kebencian dalam bentuk melaporkan dimana sesuatu yang belum tentu terbukti kebenarannya dilaporkan kepada publik dengan menunjukkan rasa kebencian.

\section{e) Menuntut}

Fungsi dari tindak tutur asertif mentutut adalah memberikan sebuah tuntutan yang dianggap penutur kurang tepat sehingga perlu dilakukan perbaikan. Meskipun demikian, tuntutan di dalam ujaran kebencian lebih didominasi emosi dibandingkan dengan akal sehat sehingga tuturan tersebut lebih menunjukkan ke sisi penghinaan dan makian dibandingkan maksud tujuan tuturan itu sendiri. Sebagai contoh ada pada data di bawah ini:

(3E) Cebong sekolam ga pake masker..kok nggak disidik

(Sumber berita: Kerumunan Terjadi Saat Kunjungan Presiden - 24 Februari 2021)

Pernyataan dari data (3E) adalah sebuah tuntutan penutur yang meminta persamaan perlakuan hukum antara pihak pendukung dengan pihak oposisi pemerintahan. Akan tetapi didalam ujaran kebencian tersebut penutur menunujukkan tuntutan tersebut dengan hinaan dan makian sehingga menutupi tujuan awal dari tujuan tuturan tersebut.

\section{Fungsi Direktif}

Fungsi direktif adalah suatu tuturan yang berfungsi untuk meminta lawan tutur melakukan sesuatu untuk menghasilkan suatu efek terhadap tindakan yang dilakukan oleh penutur. Di dalam ujaran kebencian bentuk permintaan tersebut bisa dengan katakata kasar maupun sindiran yang dipenihi kebencian. Adapun fungsi direktif yang ditemukan dalam ujaran kebencian di media online BABE ini terdiri dari bentuk bertanya, menasihati, memesan, merekomendasikan, dan memerintah.

a) Bertanya

Fungsi tindak tutur direktif bertanya adalah memberikan sebuah pertanyaan kepada mitra tutur dengan tujuan agar 
mitra tutur dapat memberikan jawaban atau setidaknya memikirkan pertanyaan dari penutur. Sebagai contoh ada pada data di bawah ini:

(4A) Bagaimana dengan cebong koruptor?

(Sumber berita: FPI Dibubarkan, Pemerintah Anggap FPI Berbahaya - 30 Desember 2020)

Pernyataan data (4A) merupakan fungsi direktif dengan bentuk bertanya. Pada penuturan, penutur mencoba menanyakan kepada pembaca terkait kondisi koruptor di Indonesia yang dianggap penutur lebih membahayakan daripada kasus HRS dan FPI. Tuturan ini juga berupa provokasi kepada pihak pendukung pemerintahan bahwa mereka adalah para koruptor yang berlindung pada pemerintah saja.

b) Menasehati

Fungsi tindak tutur direktif menasehati adalah memberikan anjuran kepada mitra tutur dengan maksud agar mitar tutur percaya dan terpengaruh dengan hal yang disampaikan penutur. Sebagai contoh ada pada data di bawah ini:

(4B) Rakyat HARUS BERGERAK Menegakan KEBENARAN, kesalahan dan KEMUNGKARAN harus dihentikan

(Sumber berita: Kerumunan Terjadi Saat Kunjungan Presiden - 24 Februari 2021)

Penuturan pada data (4B) merupakan salah satu bentuk ujaran kebencian yang disampaikan dalam bentuk nasihat. Pada penuturan penulis menyampaikan bahwa rakyat harus bergerak menegakan kebenaran. Namun secara tersirat penutur menghasut mitra tutur bahwa pemerintahan saat ini adalah sumber kemungkaran yang harus dilawan.

\section{c) Memesan}

Fungsi dari tindak tutur direktif memesan adalah memberikan sebuah saran atau pesan kepada mitra tutur sehingga mitra tutur dapat melakukan sesuatu. Akan tetapi pesan-pesan tersebut dalam ujaran kebencian lebih menojolkan sisi permusuhan dan ancaman.

Sebagai contoh ada pada data di bawah ini:

(4C) Preet kamu syoiton yg terkutuk. Mohon polisi segera menangkap orang biadap ini mumpung belum dimasa (Sumber berita: Munarman Sebut FPI Tak Mengkafirkan Orang Seperti ISIS 19 Februari 2021)

Pernyataan pada data (4C) merupakan salah satu fungsi direktif berbentuk memesankan sesuatu kepada pihak tertentu. Adapun pesan tersebut adalah pesan yang disampaikan kepada pihak kepolisian agar menangkap Novel Bakuminin yang dianggap pernyataannya meresahkan masyarakat. Pesan tersebut bersifat subjektif tanpa bukti yang jelas dan hanya menampilkan hinaan serta ancaman terhadap subjek tuturannya saja. Hal ini menunjukkan bahwa ujaran kebencian berbentuk pesan tidak lain hanya luapan perasaan saja tanpa tujuan yang baik.

d) Merekomendasikan

Fungsi tindak tutur direktif merekomendasikan adalah memberikan anjuran terhadap mitra tutur agar melakukan sesuatu yang dianggap penutur itu benar. Bentuk merekomendasikan cenderung memberikan masukan ataupun saran kepada objek penuturan secara tidak langsung. Sebagai contoh ada pada data di bawah ini:

(4D) Pemerintah harusnya sibuk menuntaskan para koruptor yg di sekeliling... jangan pura2 plongo 2 dan mencari kambing hitam utk menutupi. Rakyat sudah muak dengan kesederhanaan palsu

(Sumber berita: Kalau Pemerintah Bilang Ini Bukan Kerumunan Ya Bukan Kerumunan, Jangan Membantah Lagi 23 Januari 2021) 
Pernyataan pada data (4D) adalah bentuk rekomendasi yang disampaikan penulis kepada pemerintah yang dianggap oleh penulis memiliki kecenderungan sibuk menjadikan perkara HRS dan FPI sebagai kambing hitam sehingga melupakan kasus korupsi yang secara prinsip lebih prioritas. Bentuk ujaran kebencian ini sebenarnya tujuannya baik sebagai saran dan kritik akan tetapi karena tidak dilandasi etika komunikasi dan kesantunan, tuturan tersebut lebih terfokus pada penghinaan yang merencahkan pemerintah saja.

\section{e) Memerintah}

Fungsi dari tindak tutur direktif memerintah adalah menyampaikan suatu perintah dengan maksud agar mitra tutur melakukan sesuatu sesuai keinginan penutur. adapun notasi yang membuktikan pernyataan sebagai perintah adalah adanya pemaksanaan terhadap tindakan yang dilakukan. Dalam ujaran kebencian, perintah tersebut cenderung berbentuk ancaman yang tidak terlihat maksud dan tujuannya. Sebagai contoh ada pada data di bawah ini:

(4E) FPI dan Rizig harus dibumi hanguskan

(Sumber berita: FPI Dibubarkan, Pemerintah Anggap FPI Berbahaya - 30 Desember 2020)

Pernyataan pada data merupakan fungsi direktif berbentuk memerintah. Adapun perintah yang diberikan kepada masyarakat dan pihak yang berwajib agar membumi hanguskan FPI dan HRS. Perintah ini berbentuk luapan kebencian bernada ancaman dan tidak ada tujuan perintah yang jelas. Berbeda dengan bentuk mengancam dalam fungsi komisif, ancaman ini tidak langsung ditunjukan kepada objek kebenciannya tetapi melalui bentuk perintah kepada pihak lain untuk menyerang objek kebenciannya.

\section{Fungsi Komisif}

Fungsi komisif adalah suatu tuturan yang berfungsi mengikat penuturnya untuk melaksanakan apa yang disebutkan didalam tuturannya. Fungsi komisif ini terdiri atas 2 tipe, yaitu promises (menjanjikan) dan offers (menawarkan) sehingga terikat pada suatu di masa depan.. Adapun fungsi komisif yang ditemukan dalam ujaran kebencian di media online BABE ini terdiri dari bentuk memanjatkan doa, menawarkan, menentang, menantang, mengancam, berjanji, bersumpah

a) Memanjatkan doa

Fungsi tindak tutur direktif memanjatkan doa adalah untuk menyatakan permohonan (harapan atau permintaan) kepada Tuhan yang ditujukan kepada mitra tutur atau orangorang tertentu. Akan tetapi fungsi ini terkadang dijadikan sebagai alat ujaran kebencian ketika doa yang ditujukan adalah doa yang tidak baik dan menyerang orang lain dengan rasa permusuhan. Sebagai contoh ada pada data di bawah ini:

(5A) Sobat! Tolong aminkan do'aku ini, "Smoga allah cpat mnghukum pemimpin yg tdk adil" aamiin

(Sumber berita: Kalau Pemerintah Bilang Ini Bukan Kerumunan Ya Bukan Kerumunan, Jangan Membantah Lagi 23 Januari 2021)

Pernyataan pada data (5A) adalah bentuk fungsi komisif dengan bentuk memanjatkan doa. Adapun doa yang disampaikan oleh penutur adalah "Smoga allah cpat mnghukum pemimpin yg tdk adil". Walaupun terlihat seperti doa yang bertujuan baik akan tetapi tuturan tersebut menjadi sebuah ujaran kebencian ketika konteks dimana ditulisnya doa itu tidak tepat. Doa itu menjadi sebuah hasutan kepada masyarakat bahwa pemerintah melakukan ketidakadilan dan cenderung menguatkan rasa permusuhan kepada pemerintah. 
b) Menawarkan

Fungsi tindak tutur komisif menawarkan adalah untuk mengemukakan pilihan atau memberikan tawaran kepada lawan tutur. Namun pada ujaran kebencian berbentuk tawaran, tuturan ini bertujuan untuk menyerang objek kebenciannya sehingga menimbulkan kerugian bagi pihak tertentu saja. Sebagai contoh ada pada data di bawah ini:

(5B) Sdh dipastikan cebong junior ini akan jadi walkot solo, jadi percuma diadakan pilkada, mending dananya buat rakyat solo saja.

(Sumber berita: Gibran Teguh dapat Rekomendasi Megawati, Gibran: Saya Minta Doa yang terbaik - 16 Juli 2020)

Pernyataan pada data (5B) merupakan salah satu bentuk dari fungsi komisif menawarkan. Adapun tawaran yang disampaikan oleh penutur adalah pemanfaatan dana pilkada untuk masyarakat solo daripada dihabiskan untuk keperluan pilkada yang menurut penutur sudah ditentukan pemenangnya. Penutur disini menyebarkan berita bohong kepada masyarakat bahwa pilkada sudah diatur sedemikian rupa sehingga lebih baik hal itu ditiadakan dan dana pilkada tersebut untuk hal yang lain saja.

\section{c) Menentang}

Fungsi tindak tutur direktif menentang adalah untuk menyatakan ketidaksetujuan terhadap suatu hal. Oleh karena itu, tuturan bersifat penolakan ini bisa dalam bentuk penolakan terhadap suatu kebijakan tertentu atau bisa juga menolak keberadaan orang-orang tertentu. Dalam ujaran kebencian, penolakan ini pasti tidak diikuti dengan bentuk kesantunan dan hanya penolakan dengan rasa kebencian saja.

Sebagai contoh ada pada data di bawah ini:

(5C) Tuh preman berkedok agama, bisanya koar-koar tapi nol besar
(Sumber berita: Pemerintah: FPI Banyak Melanggar Ketentuan Ormas - 31 Desember 2020)

Pernyatan pada data (5C) merupakan salah satu bentuk fungsi komisif yang berwujud menentang. Penutur disini menolak untuk merepresentasikan FPI sebagai ulama tetapi lebih sebagai preman berkedok agama saja.

d) Menantang

Fungsi tindak tutur direktif menantang adalah untuk mengajak melakukan sesuatu perbuatan dalam bentuk tantangan kepada pihak tertentu. Oleh karena itu, tuturan ini cenderung bersifat provokasi atau menghasut yang dapat memancing amarah orang-orang tertentu dan melakukan perlawanan atau memberontak. Sebagai contoh ada pada data di bawah ini:

(5D) Selama rezim ini berkuasa kalian seneng berkoar...Tunggu wktunya selesai kalian gk bakalan bisa apa pa, bersenang senanglah dahulu kalian

(Sumber berita: Kerumunan Terjadi Saat Kunjungan Presiden - 24 Februari 2021)

Pernyataan pada data merupakan salah satu bentuk fungsi komisif dalam wujud manantang. Tantangan yang disampaikan oleh penutur tersebut adalah sebuah ancaman di masa mendatang. Penutur menantang pihak pendukung untuk bersenangsenang dahulu karena di masa mendatang para pendukung pemerintah tersebut akan menerima pembalasan yang lebih buruk.

e) Mengancam

Fungsi tindak tutur komisif mengancam adalah untuk mencelakakan lawan tutur atau memberikan peringatan tentang petaka yang akan terjadi. Oleh karena itu, tuturan ini bersifat ancaman yang diberikan kepada pihak-pihak tertentu yang menjadi objek kebencian. Sebagai contoh ada pada data di bawah ini: 
(5E) Gantung dan kuliti sekujur badannya...biar rijiek teriak teriak merasakan kesakitan yang luar biasa

(Sumber berita: Mahmud MD Putar Video Pimpinan FPI Dukung ISIS - 30 Desember 2020)

Pernyataan pada data (5E) merupakan salah satu bentuk fungsi komisif yang berwujud ancaman yang disampaikan oleh penutur pada kolom komentar. Ancaman yang diberikan adalah ancaman kepada HRS yang akan digantung dan dikuliti jika terus melakukan kerusakan. Ancaman tersebut sebenarnya hanya luapan kebencian oknum tertentu saja, akan tetapi karena ancaman tersebut sudah merujuk pada orang tertentu maka ancaman ini sebenarnya sudah bisa dibawa ke ranah hukum.

\section{f) Berjanji}

Fungsi tindak tutur komisif berjanji adalah tuturan yang disampaikan penutur dengan maksud akan berbuat atau melakukan sesuatu di masa depan. Oleh karena itu, tuturan ini bersifat mengikat penutur kepada tindakan yang akan datang karena berbentuk janji baik kepada diri sendiri maupun orang lain. Sebagai contoh ada pada data di bawah ini:

(5F) JABATAN ada batasnya, KALIAN KAMI Pastikan, akan mengalami PEMBALASAN yg LEBIH Menyakitkan dan BUKAN hanya kepada Pelaku saja KAMI akan KEJAR semua Orang yg terkait yg MENIKMATI dan TERLIBAT Langsung dan tdk langsung atas pelangaran kejahatan kalian

(Sumber berita: Kalau Pemerintah Bilang Ini Bukan Kerumunan Ya Bukan Kerumunan, Jangan Membantah Lagi 23 Januari 2021)

Pernyataan pada data (5F) merupakan bentuk fungsi komisif dalam wujud berjanji. Adapun janji yang disampaikan adalah pembalasan terhadap para pendukung rezim dan pelaku tindakan yang dianggap penutur sebagai tindakan zhalim kepada pihak HRS dan FPI. Penutur

g) Bersumpah

Fungsi tindak tutur komisif bersumpah adalah mengutuk atau menghukum dalam jangka seumur hidup orang yang bersangkutan. Oleh karena itu tuturan ini bersifat kejam atau tidak menaruh belas kasihan kepada orang yang menerima sumpah tersebut.

Sebagai contoh ada pada data di bawah ini:

(5G) Sumpah aq klo ktm Novel ini pingin aq sumpal mulutnya dgn sandal manusia jahanam.

(Sumber berita: Novel Bakmumin Kritisi Langkah TNI Turunkan Baliho Rizieq Shihab - 21 November 2020)

Pada data (5G), sumpah yang disampaikan adalah keinginan penutur untuk menyumpal mulut Novel dengan sandal karena penutur merasa mulut Novel tidak bisa dijaga. Adapun penanda lingual ini dibuktikan dengan kata "sumpah" yang disampaikan di awal kalimat. Tuturan ini bersifat ancaman yang sebenarnya hanya omong kosong saja karena penutur hanya meluapkan kemarahan dan kebencian saja tanpa mengatur apa yang sebenarnya dia tuturkan.

\section{Fungsi Ekspresif}

Fungsi ekspresif adalah suatu tuturan yang dimaksudkan penuturnya agar ujarannya diartikan sebagai evaluasi tentang hal yang disebutkan didalam tuturan itu Adapun fungsi asertif yang ditemukan dalam ujaran kebencian di media online BABE ini terdiri dari bentuk mengucapkan selamat, membela, mengkritik, menyindir, menyalahkan, dan menghina.

a) Mengucapkan selamat

Fungsi dari tindak tutur ekspresif mengucapkan selamat umumnya adalah 
untuk memberikan selamat atas sebuah pencapaian. Akan tetapi dalam ujaran kebencian, tuturan ini berbentuk selamat atas pencapaian yang tidak baik dan diungkapkan dengan rasa permusuhan dan kebencian. Sebagai contoh ada pada data di bawah ini:

(6A) Bersyukurlah kalau ada yang mendengar ceramahmu, ceramahmu tak beda dengan sampah.

(Sumber berita: Pemerintah: FPI Banyak Melanggar Ketentuan Ormas - 31 Desember 2020)

Pernyataan pada data (6A) merupakan bentuk fungsi ekspresif yang diwujudkan dalam mengucapkan selamat. Adapun pada pernyataan ini merupakan sebuah ucapan selamat atas pencapaian objek tuturan yang bisa membuat orang lain mendengarkan ceramah dari objek tuturan tersebut walaupun ceramahnya dianggap penutur tidak lebih dari sampah.

b) Membela

Fungsi tindak tutur ekspresif membela adalah untuk membantu atau melindungi mitra tutur dari suatu masalah. Oleh karena itu, tuturan ini bersifat memihak kepada orang dibela oleh penutur. Sebagai contoh ada pada data di bawah ini:

(6B) Otak babi terbalik ketularan otak gerombolan kadrun, kok dibilang pak Jokowi tersudut, yg tersudut yg bakal masuk sel tong

(Sumber berita: FPI Siap-Siap Dibubarkan, Jokowi Makin Tersudut - 28

Desember 2020)

Pernyatan pada data (6B) merupakan salah satu bentuk fungsi ekspresif yang melakukan pembelaan. Adapun pembelaan yang dilakukan oleh salah satu pendukung Jokowi ini disebabkan adanya perasaan tidak terima bila presiden dikatakan tersudut. Akan tetapi dalam ujaran kebencian, pembelaan ini sering diikuti dengan ungkapan permusuhan dan kebencian kepada orang yang menyerang nama baik Jokowi.

c) Mengkritik

Fungsi tindak tutur ekspresif mengkritik adalah untuk mengomentari atau menanggapi suatu pendapat atau suatu kejadian yang tidak disukai oleh penutur. Oleh karena itu, tuturan ini lebih banyak berbentuk celaan atau kecaman dan menjadi bentuk tuturan yang palimg banyak pada kajian ujaran kebencian di media sosial karena netizen lebih suka mengkritik daripada memuji. Sebagai contoh ada pada data di bawah ini:

(6C) itulah klu mengandalkan pencitraan, ketahuan juga belangnya

(Sumber berita: Dulu Jadi Relawan Jokowi, Tokoh NU Kini Kecewa: Jokowi Luntur ke Jokowiannya - 12 Oktober 2020)

Pernyataan pada data (6C) merupakan salah satu bentuk fungsi ekspresif pada mengkritik. Adapun kritikan ditujukan kepada pemerintah yang dianggap oleh penutur sebagai pemerintah yang mengandalkan pencitraan saja.

d) Menyindir

Fungsi tindak tutur ekspresif menyindir adalah untuk memberikan kritikan atau mengejek mitra tutur secara tidak langsung. Oleh karena itu, tuturan ini bersifat celaan yang tersirat atau mengatakan sebuah pujian tetapi bermakna buruk atau kebalikan dari yang diungkapkan. Sebagai contoh ada pada data di bawah ini:

(6D) wah hebat ya, nangkap satu orang kayak mau perang. Bos gimana dengan papua yang sudah banyak korban?

(Sumber berita: Eks Petinggi FPI ditangkap oleh Densusu 88 - 27 April 2021)

Pernyataan pada data (6D) merupakan salah satu bentuk fungsi ekspresif menyindir. Adapun sindiran yang disampaikan kepada pemerintah 
yang mampu dengan cepat menangkap orang yang berasal dari FPI sedangkan disaat bersamaan masalah teroris di Papua tidak juga kunjung terselesaikan.

e) Menyalahkan

Fungsi tindak tutur ekspresif menyalahkan adalah ingin melemparkan kesalahan kepada pihak-pihak tertentu. Oleh karena itu, tuturan ini biasanya bersifat teguran keras atau tuduhan. Sebagai contoh ada pada data di bawah ini:

(6E) Sampah masyarakat, model gini kok dianggep ulama, kostumnya ga salah pake tuh..ganti aja kostum badut

(Sumber berita: Habib Rizieq: Pemerintah Tebang Pilih, Kasus Raffi Ahmad Dihentikan - 22 Januari 2021)

Pernyataan pada data (6E) merupakan bentuk fungsi ekspresif dalam wujud menyalahkan. Adapun objek yang disalahkan adalah FPI dan HRS yang menggunakan pakaian ulama namun perbuatannya bagi penutur menunjukan seperti sampah masyarakat.

f) Menghina

Fungsi tuturan ekspresif menghina adalah untuk mempermalukan, menjelekkan nama baik atau menyinggung perasaan mitra tutur. Oleh karena itu, tuturan ini bersifat merendahkan derajat orang-orang yang dihina karena memang tuturan ini ditujukan untuk sesorang atau sesuatu yang dibenci oleh penutur. Sebagai contoh ada pada data di bawah ini:

(6F) Pecundang kau jik

(Sumber berita: Habib Rizieq:

Pemerintah Tebang Pilih, Kasus Raffi

Ahmad Dihentikan - 22 Januari 2021)

Pernyataan di atas adalah bentuk fungsi ekspresif yang menghina. Adapun objek yang dihina adalah Habib Rizieq yang disebutkan dalam penuturan sebagai pecundang. Pernyataan ini didasarkan persepsi penulis yang merasa Habib
Rizieq hanya membuat kerusakan melalui ormas FPI nya saja.

\section{SIMPULAN}

Penelitian ini mengklasifikasikan ujaran kebencian dalam tiga penanda lingual yaitu kata, frasa, dan tuturan. Makna tindak tutur dalam ujaran kebencian adalah bersifat ilokusi karena setiap ujaran tersebut terikat dengan konteks. Makna kontekstual itulah yang membagi ujaran kebencian menjadi tujuh kategori antara lain penghinaan, pencemaran nama baik, penistaan, perbuatan tidak menyenangkan, provokasi, penghasutan, dan berita bohong. Sedangkan untuk fungsi tindak tutur yang muncul terdapat empat fungsi yaitu fungsi asertif, direktif, komisif, dan ekspresif. Fungsi asertif yang muncul terdiri dari bentuk berspekulasi, menyebutkan, menunjukan, melaporkan, dan menuntut; fungsi direktif yang muncul terdiri dari bentuk bertanya, menasihati, memesan, merekomendasikan, dan memerintah; fungsi komisif yang muncul terdiri dari bentuk memanjatkan doa, menawarkan, menentang, menantang, mengancam, berjanji, bersumpah, dan fungsi ekspresif yang muncul terdiri dari bentuk mengucapkan selamat, membela, mengkritik, menyindir, menyalahkan, dan menghina.

\section{DAFTAR PUSTAKA}

Austin, John Langshaw. (1962). How to Do Things With Words. Oxford: Oxford University Press.

Chaer, Abdul. (2010). Kesantunan berbahasa. Jakarta: PT Rineka Cipta.

Cohen, Henri, and C. Claire Lefebvre. (2005). Handbook of Categorization in Cognitive Science. Amsterdam: Elsevier. 
Haryatmoko. (2011). Etika Publik. Jakarta: PT Gramedia Pustaka Utama.

Hirsch, Susan F. (2008). Putting Hate Speech in Context: Observation on Speech, Power, and Violence in Kenya. George Mason University. Diakses tanggal 2 Agustus 2020

http://www.ushmm.org.m.pdfs/20100423 -speech-power-violence-hirsch.pdf.

Isasi, Alex Cabo and Ana García Juanatey. (2016). El discurso del odio en las redes sociales: Un estado de la cuestión. Ajuntament de Barcelona progress report. Diakses tanggal 12 Januari 2021

http://ajuntament.barcelona.cat/bcnvsodi/ wpcontent/uploads/2017/02/Inform e_discurso-del-odio_ES.pdf.

Kapolri. (2015). Penanganan Ujaran Kebencian. Surat Edaran Kapolri Nomor SE/06/X/2015. Jakarta

Linawati. (2017). “Tindak Tutur Ujaran Kebencian dalam Komentar Pembaca pada Surat Kabar Online Tribunnews.com". (Skripsi). Yogyakarta: Program Studi Bahasa Indonesia, Universitas Negeri Yogyakarta

Mawarti, Sri. (2018). Fenomena Hate Speech: Dampak Ujaran Kebencian. Toleransi, 10 (1). hlm 83-95

Ningrum, Dian Junita. (2018). Kajian Ujaran Kebencian di Media Sosial, Jurnal Ilmiah Korpus, 2(3).hlm 241-252

Nasrullah, R. (2017). Media Sosial: Perspektif Komunikasi, Budaya, dan Sosioteknologi. Bandung: Remaja Rosdakarya.

Sudaryanto. (2015). Metode dan Aneka Teknik Analisis Bahasa: Pengantar
Penelitian Wahana Kebudayaan secara Linguistik. Yogyakarta: Senata Dharma University Press.

Syafyahya, Leni. (2018). Ujaran Kebencian dalam Bahasa Indonesia: Kajian Bentuk dan Makna. Makalah Kongres KBI 2018. Universitas Andalas, Sumatera Barat, Indonesia

Yule, George. (2006). Pragmatik (edisi terjemahan oleh Indah Fajar Wahyuni dan Rombe Mustajab). Yogyakarta: Pustaka Pelajar. 